\title{
The first-year experience of a university hospital laser unit
}

\author{
Üniversite hastanesi lazer ünitesi ilk yıl deneyimleri
}

\section{Deniz Aksu Arıca, ๑ Leyla Baykal Selçuk, ๑ Savaș Yaylı, ๑ Simay Bayrak, ๑ Sevgi Bahadır}

Karadeniz Technical University Faculty of Medicine, Department of Dermatology and Venereology, Trabzon, Turkey

\begin{abstract}
Background and Design: The aim of this study was to evaluate the efficacy and safety of neodymium-doped yttrium aluminum garnet (Nd:YAG) laser and intense pulsed light (IPL) systems, and the variety of indications involved.

Materials and Methods: First-year treatments in our clinic were evaluated retrospectively. Results were classified according to improvement rates: $<25 \%$ as mild improvement; $25-75 \%$ as moderate improvement and $>75 \%$ as excellent improvement.

Results: One hundred thirty-three patients aged 3-79 years (mean: 35.91) with 14 different indications were treated. Pigmented lesions were treated with IPL, and vascular lesions with IPL and/or Nd:YAG. Combined therapy with IPL and Nd:YAG at two-week intervals resulted in excellent improvement in $70.21 \%$ of vascular lesions (34 rosacea, 8 nevus flammeus, and 5 hemangioma), and moderate improvement in the rest. Telangiectasia and angiomatous lesions exhibited excellent improvement in $93.65 \%$ of patients with Nd:YAG, and moderate improvement in the rest. IPL resulted in excellent improvement in $78.49 \%$ of cases of solar lentigo, and moderate improvement in the rest. Moderate improvement was observed in $66.67 \%$ of patients with melasma using IPL, and mild improvement in the rest. Pain scores were significantly lower with Nd:YAG than IPL ( $\mathrm{p}<0.05)$. Complications related to treatment were observed in 3 patients (vesicles in two patients and atrophic scar in 1), all of which developed after Nd:YAG laser application.

Conclusion: Nd:YAG and IPL were successful with very low side-effect rates in a wide range of indications. Our study is the first evaluation of the efficacy of Nd:YAG and IPL combination therapy applied at 2-week intervals, and high efficiency was observed with no increase in any complication rate by intermittently combining different wavelengths.
\end{abstract}

Keywords: Laser therapy, rosacea, port-wine stain, lentigo, hemangioma, telangiectasia

\section{Öz}

Amaç: Çalışmamızda neodim-itriyum alüminyum garnet (Nd:YAG) lazer ve yoğun atımlı ışı (IPL) sistemlerinin etkinlik ve güvenilirliğini belirlemenin yanı sıra endikasyon çeşitliliğinin değerlendirilmesi amaçlandı.

Gereç ve Yöntem: Kliniğimizde ilk bir yılda yapılan uygulamalar retrospektif olarak değerlendirildi. Tedavi sonuçları elde edilen düzelme oranlarına göre; <\%25 hafif, \%25-75 orta ve >\%75'ten fazla, çok iyi düzelme olarak sınıflandırıldı.

Bulgular: On dört farklı endikasyonda, toplam 133 hastaya tedavi uygulandı. Hastaların yaşları 3 ile 79 arasında değişmekteydi (ortalama 35,91). Pigmente lezyonların tamamına IPL, vasküler lezyonlara ise IPL ve/veya Nd:YAG tedavisi uygulandı. iki hafta arayla IPL ve Nd:YAG tedavilerinin kombine uygulandığı vasküler lezyonlarda (34 rozase, 8 nevüs flammeus, 5 hemanjiyom) \%70,21 oranında çok iyi düzelme, geri kalanında da orta derecede düzelme elde edildi. Telanjiektazi ve anjiyomatöz lezyonlarda Nd:YAG lazer tedavisi \%93,65 oranında çok iyi, geri kalanında orta derecede düzelme ile sonuçlandı. Solar lentigolarda IPL ile \%78,49 oranında çok iyi, geri kalanında orta derecede düzelme saptandı. Melasmada ise IPL ile \%66,67 oranında orta derecede düzelme gözlenirken, geri kalanında düzelme hafif derecede kaldı. Nd:YAG lazerde ağıı skoru, IPL'ye göre anlamlı derecede düşük bulundu $(p<0,05)$. Tedaviye bağlı komplikasyon gelişimi sadece üç hastada (iki hastada vezikül, bir hastada atrofik skar) gözlendi, bunların 3'ü de Nd:YAG lazer uygulama sonrası gelişmiştir.

Sonuç: Nd:YAG ve IPL tedavileri, geniş bir endikasyon alanında, oldukça düşük komplikasyon oranlarıyla başarılı bulunmuştur. Çalışmamızda iki hafta arayla uygulanan Nd:YAG ve IPL kombinasyon tedavisinin etkinliği ilk kez değerlendirilmiştir, bu şekilde farkı dalga boylarının aralıkl kombine edilmesiyle yüksek etkinlik izlenirken komplikasyon oranında herhangi bir artış saptanmamıştır.

Anahtar Kelimeler: Lazer tedavisi, rozase, porto şarabı lekesi, lentigo, hemanjiyom, telanjiektazi

Address for Correspondence/Yazışma Adresi: Deniz Aksu Arıca MD, Karadeniz Technical University Faculty of Medicine, Department of Dermatology and Venereology, Trabzon, Turkey Phone: +90 4623775127 E-mail: drdenizaksu@gmail.com

Received/Geliş Tarihi: 14.02.2018 Accepted/Kabul Tarihi: 19.07.2018 ORCID ID: orcid.org/0000-0003-3755-4325

CCopyright 2019 by Turkish Society of Dermatology and Venereology

Turkderm-Turkish Archives of Dermatology and Venereology published by Galenos Yayınevi. 


\section{Introduction}

The term laser is an acronym for "Light amplification by stimulated emission of radiation" and refers to a beam of light amplified by the concentration of stimulated radiation. Since they were first developed, laser systems have been increasingly successfully used in various medical fields, and particularly dermatology, for approximately 50 years. Laser systems are used in the treatment of various different conditions, such as vascular lesions, pigmented lesions, scars and striae, as well as for tattoo removal, epilation, and skin renewal aimed at the elimination of wrinkles. However, these costly devices are usually found in cosmetology clinics. This results in their use being concentrated on cosmetic indications. Expanding the establishment of laser units in university hospitals will be useful in broadening these areas of indication and in the more effective use of laser systems.

Neodymium-doped yttrium aluminum garnet ( $\mathrm{Nd}$ :YAG) laser and intense pulsed light (IPL) procedures have been performed for various indications in the laser unit established in our clinic for more than one year. This retrospective study reviews the results of therapeutic applications in our laser unit.

The purpose of the study was to reveal our laser unit's first year experience and the favorable effect and side-effect rates. We anticipate that this review of our treatment indications and results will assist with more effective laser therapy procedures and will shed light on future studies.

\section{Materials and Methods}

Data forms concerning procedures performed for the year following the opening of the laser unit within the body of our university hospital dermatology and venereology department were evaluated retrospectively. Patients' demographic characteristics, Fitzpatrick skin types, diagnoses, treatments administered, degrees of improvement in lesions before and after treatment, and complications developing were recorded on these forms. Disease severity in patients diagnosed with rosacea was evaluated using the method of calculating rosacea severity score described by Say et al. ${ }^{1}$ Rosacea was evaluated in two distinct groups: Papulopustular rosacea (PPR) and erythematotelengiactic rosacea (ETR), and scored accordingly on the data forms. Pain associated with the procedure was scored by the patient using a numerical scale, and was again recorded onto the form. Digital photographs of the patients were taken before and after treatment at each session.

\section{Treatment Application}

A Xeo laser device [(Xeo laser device, Cutera Inc., Brisbane, CA, United States of America (USA)] was used in our study. This device has two options, Nd:YAG laser and IPL. The IPL device has three programs: A (520 nm wavelength, 2-12 ms pulse width), B (560 nm wavelength, 5-29 ms pulse width), and C (580 nm wavelength, 10-60 ms pulse width).

Treatments in our study were applied with parameters selected based on all indications and the patient's skin type. Treatments were administered using Aquasonic ${ }^{\circledR} 100$ ultrasound gel (Parker Lab, Inc. Fairfield, New Jersey 07004, USA) and by a single specialist.

Cold application for 5-10 minutes and medium-potency topical corticosteroid cream use for one to three days were recommended depending on signs of inflammation developing after sessions. All patients were notified of the need for protection against the sun, from the time of laser therapy planning and for at least 3 months after the end of treatment. Sessions were performed at 2- to 4-week intervals. Presence of any complications was recorded at controls in the second week after procedures, and additional applications were performed in case of necessity.

\section{Evaluation of the Efficacy of Treatment}

The efficacy of treatment was evaluated separately by the patient and the physician. Digital photographs taken before and after treatment were used in this evaluation. Based on the rates of improvement achieved, treatment results were classified as 0-25\% - mild improvement, 25-75\% - moderate improvement, and over 75\% - excellent improvement. The study was approved by the Karadeniz Technical University Faculty of Medicine Clinical Research Ethics Committee (approval number: 43, date: 2017), and written informed consent have been obtained from the patients.

\section{Statistical Analysis}

Data analysis was performed using SPSS 22.0 software. Data were expressed as number, percentage (\%), and arithmetic mean \pm standard deviation. Descriptive statistics and a chi-square test were used for data analysis. A p value of less than 0.05 was considered statistically significant.

\section{Results}

A total of 133 patients (58 female, 75 male) were treated in the first

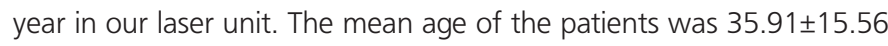
(3-79) years. Eighty-eight patients had Fitzpatrick skin type 2, 35 - type 3, one patient - type 1, and one had type 4.

One hundred eleven patients were treated for vascular lesions, and 25 for pigmented lesions. Both vascular and pigmented lesions were present in 3 patients. The selected treatment was IPL in all pigmented lesions. In the case of vascular lesions, IPL alone, or Nd:YAG alone, or the two in combination in consecutive sessions at least 2 weeks apart were applied in treatment. IPL was applied in 73 patients for various indications, and Nd:YAG therapy in 110. IPL and Nd:YAG were used in combination in different sessions at intervals of at least 2 weeks in 47 patients. In addition, Nd:YAG in genesis mode $(5 \mathrm{~mm}$ spot diameter, $14 \mathrm{j} / \mathrm{cm}^{2}$ energy, $0.3 \mathrm{~ms}$ pulse width, $10 \mathrm{~Hz}$ frequency) was applied in 4 cases of keloid, atrophic scar and onychomycosis. The total number of sessions administered ranged between 1 and 9 (mean: 1.98 1.29). Treatment was applied in 14 for different indications. Thirty-four patients were treated in our unit for rosacea, 29 for spider angioma, 28 for telangiectasia, 19 for solar lentigo, 9 for nevus flammeus, 5 for hemangioma, 5 for cherry angioma, 3 for melasma, 2 for keloid, 1 for atrophic scar, 2 for poikiloderma (1 poikiloderma of Civatte, the other scleroderma-related poikiloderma), 1 for onychomycosis, 1 for axillary freckling secondary to neurofibromatosis, and 1 for venous lake. The treatments administered, session numbers, and improvement levels are summarized in Table 1.

Complications developed in 3 patients, vesicles in 2, and depigmented atrophic scar in 1. These complications all developed following $\mathrm{Nd}$ :YAG laser application. 
When pain severity was assessed using a numerical scale from 0 (no pain) to 10 (unbearable pain), the mean pain score in patients receiving treatment with IPL and Nd:YAG was 5.26 and 2.92, respectively. The difference was statistically significant $(p<0.05)$. In terms of pain scores, Nd:YAG was more tolerable than IPL procedures. Two patients reporting severe pain in the first session received topical anesthesia with $5 \%$ EMLA $^{\circledR}$ cream occlusion at least half an hour prior to the subsequent sessions.

IPL and Nd:YAG were used in combination in 34 patients with rosacea ( 2 with severe and 30 with moderate ETR, and 1 with moderate and 1 with mild PPR). In the first session, Nd:YAG laser therapy was applied by tracing vessels over the telangiectasia (3 mm spot diameter, 120-150 $\mathrm{j} / \mathrm{cm}^{2}$ energy, and 10-15 ms pulse width). At the end of two weeks, treatment continued with IPL (14-24 j/ $\mathrm{cm}^{2}$ in A or B mode). In patients receiving IPL once every four weeks, areas in which telangiectasia was observed at 2-weekly controls between sessions were treated with Nd:YAG. At the end of the sessions (varied between 2 and 6), improvement exceeding 75\% was observed in 28 patients with ETR, 2 severe and the remainder moderate. Treatment concluded with moderate improvement in the remaining 6 cases (2 PPR, and 4 moderate ETR) (Figure 1). Five patients with almost complete resolution at the end of 6-month follow-up presented to our clinic due to recurrence of erythema, and these were again enrolled in the treatment plan.

$\mathrm{Nd}$ :YAG therapy (3 mm spot diameter, 120-150 j/ $\mathrm{cm}^{2}$ energy, and 10-15 ms pulse width) was applied to all 47 lesions in 29 patients with spider angiomas. Either 1 or 2 sessions were performed, and improvement greater than $75 \%$ was observed in all patients (Figure 2). Vesicles developed in 1 patient on the day after treatment, and depigmented atrophic scar developed in another.
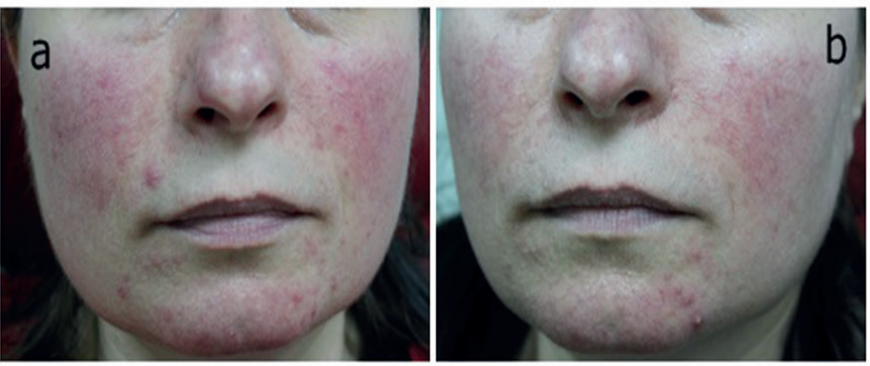

Figure 1. Comparison of photographs taken before (a) and one month after (b) combined treatment of papulopustular rosacea with neodymium-doped yttrium aluminum garnet ( $3 \mathrm{~mm}, 130 \mathrm{j} / \mathrm{cm}^{2}, 10 \mathrm{~ms}$ ) and intense pulsed light (A20) in a single session at two-week intervals shows moderate improvement in lesions with treatment

\section{Table 1. Treatments applied, session numbers, and outcomes}

\begin{tabular}{|c|c|c|c|c|c|c|c|}
\hline \multirow[b]{2}{*}{ Indication } & \multicolumn{3}{|c|}{ Number of patients treated } & \multirow{2}{*}{$\begin{array}{l}\text { Number of } \\
\text { sessions }\end{array}$} & \multicolumn{3}{|c|}{ Patient numbers in terms of treatment outcomes } \\
\hline & Nd:YAG & IPL & Combined & & $\begin{array}{l}0-25 \% \\
\text { improvement }\end{array}$ & $\begin{array}{l}25-75 \% \\
\text { improvement }\end{array}$ & $\begin{array}{l}>75 \% \\
\text { improvement }\end{array}$ \\
\hline Rosacea & - & - & 34 & $2-6$ & - & $\begin{array}{l}6 \\
17.64 \% \\
\end{array}$ & $\begin{array}{l}28 \\
82.35 \% \\
\end{array}$ \\
\hline Spider angioma & $\begin{array}{l}29 \\
\text { (47 lesion) }\end{array}$ & - & - & $1-2$ & - & - & $\begin{array}{l}29 \\
100 \%\end{array}$ \\
\hline Telangiectasia & 28 & - & - & $1-3$ & - & $\begin{array}{l}4 \\
14.29 \%\end{array}$ & $\begin{array}{l}24 \\
85.71 \%\end{array}$ \\
\hline Nevus flammeus & - & 1 & 8 & $3-9$ & - & $\begin{array}{l}5 \\
55.56 \%\end{array}$ & $\begin{array}{l}4 \\
44.44 \%\end{array}$ \\
\hline Solar lentigo & - & 19 & - & $2-4$ & - & $\begin{array}{l}4 \\
21.05 \%\end{array}$ & $\begin{array}{l}15 \\
78.94 \%\end{array}$ \\
\hline Cherry angioma & $\begin{array}{l}5 \\
\text { (28 lesion) }\end{array}$ & - & - & $1-2$ & - & - & $\begin{array}{l}5 \\
100 \% \\
\end{array}$ \\
\hline Hemangioma & - & - & 5 & $4-6$ & - & $\begin{array}{l}3 \\
60 \% \\
\end{array}$ & $\begin{array}{l}2 \\
40 \%\end{array}$ \\
\hline Melasma & - & 3 & - & $1-3$ & $\begin{array}{l}1 \\
33.33 \%\end{array}$ & $\begin{array}{l}2 \\
66.67 \%\end{array}$ & - \\
\hline Scar & 3 & - & - & 1 & $\begin{array}{l}3 \\
100 \% \\
\end{array}$ & - & - \\
\hline Axillary pigmentation & - & 1 & - & 2 & - & - & $\begin{array}{l}1 \\
100 \%\end{array}$ \\
\hline Poikiloderma & - & 2 & - & 3 & - & \begin{tabular}{|l|} 
\\
$100 \%$ \\
\end{tabular} & - \\
\hline Venous lake & 1 & - & - & 1 & - & - & $\begin{array}{l}1 \\
100 \%\end{array}$ \\
\hline Onycho-mycosis & 1 & - & - & 2 & $\begin{array}{l}1 \\
100 \% \\
\end{array}$ & - & - \\
\hline
\end{tabular}




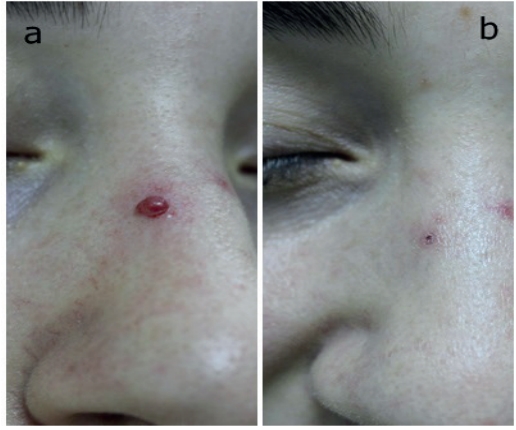

Figure 2. Comparison of photographs taken before (a) and two weeks after (b) treatment of spider angioma with neodymium-doped yttrium aluminum garnet $\left(3 \mathrm{~mm}, 140 \mathrm{j} / \mathrm{cm}^{2}, 10 \mathrm{~ms}\right)$ in a single session shows that almost complete elimination of lesions was achieved with treatment

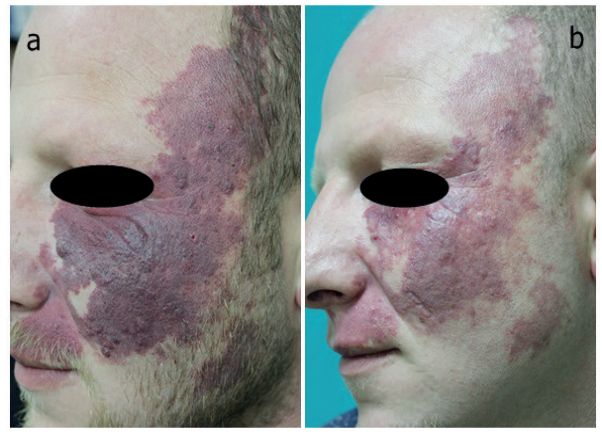

Figure 3. Comparison of photographs taken before (a) and one month after (b) combined treatment of nevus flammeus with neodymiumdoped yttrium aluminum garnet (3-5 mm, 60-120 j/cm², 10-40 ms) and intense pulsed light (A20-24) in three sessions at two-week intervals shows moderate improvement was achieved in lesions

Nd:YAG therapy (3 mm spot diameter, 100-160 j/ $\mathrm{cm}^{2}$ energy, and 10-20 ms pulse width) was applied alone in 28 patients with isolated telangiectasia. Excellent improvement was achieved in 24 patients after 1 to 3 sessions. Treatment in the remaining cases resulted in moderate improvement. However, 3 patients presented to our clinic during 10-month follow-up due to recurrence of lesions, and these lesions also regressed with repeat $\mathrm{Nd}$ :YAG laser therapy.

IPL and Nd:YAG therapies were applied in combination in 8 patients with nevus flammeus. Hypertrophic areas were first treated with $\mathrm{Nd}$ :YAG laser. In the subsequent sessions, the two therapeutic options were used consecutively in combination at 2- to 4-week intervals. $\mathrm{Nd}$ :YAG laser was applied at spot diameters of 3-7 mm, with a 60-140 $\mathrm{j} / \mathrm{cm}^{2}$ energy, and pulse widths of 10-40 ms. IPL was used at doses of $14-27 \mathrm{j} / \mathrm{cm}^{2}$ in $\mathrm{A}$ or $\mathrm{B}$ mode. Following 3 to 9 sessions, treatment was completed with excellent improvement in 3 patients and moderate improvement in 5 (Figure 3). Five patients were still receiving treatment when our study period ended. Almost complete eradication of lesions was achieved with IPL alone in another patient with nevus flammeus on the neck (Figure 4).

IPL was applied alone in 19 patients with solar lentigo. Lesions were located on the face in 7 patients and on the back of the hand in 12 . IPL was applied in sun mode, at $12-24 \mathrm{j} / \mathrm{cm}^{2}$ in A or B modes. The

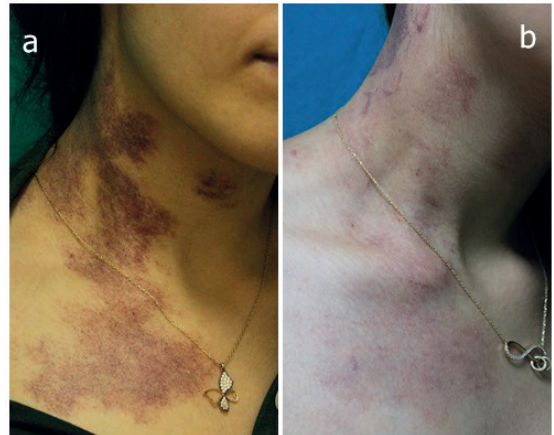

Figure 4. Comparison of photographs taken before (a) and two weeks after (b) treatment of nevus flammeus with intense pulsed light (A20-24) applied in two sessions at four-week intervals shows almost complete resolution of lesions

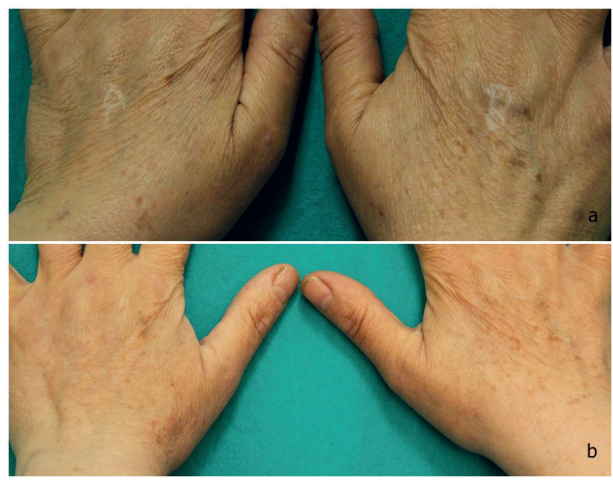

Figure 5. Comparison of photographs taken before (a) and one month after (b) of solar lentigo with intense pulsed light (B18) application to the left handand cryotherapy to the right hand shows almost entire elimination of lesions with treatment, as well as a decrease in fine wrinkles on the hand receiving IPL

number of sessions ranged between 2 and 4, and resulted in excellent improvement in all lesions on the back of the hand, while excellent improvement was achieved in 3 patients with facial lesions and moderate improvement in 4 . In addition to improvement of lesions, we also observed a decrease in photoaging signs and fine wrinkles in the skin of the hand in patients we applied IPL alone due to solar lentigines and scanned the entire back of the hand (Figure 5).

$\mathrm{Nd}$ :YAG therapy with a $3 \mathrm{~mm}$ spot diameter, 140-150 j/ $\mathrm{cm}^{2}$ energy, and 10-15 ms pulse width was applied in 28 lesions in 5 patients with cherry angioma. Complete elimination of lesions was observed in 1 or 2 sessions in all patients, although vesicle formation was observed in 1 patient on the third day after treatment.

IPL and Nd:YAG therapies were applied in combination in 5 patients with hemangioma. Nd:YAG was first applied at spot diameters of 3-7 mm, with a 50-150 j/ $\mathrm{cm}^{2}$ energy and 10-40 ms pulse width. IPL therapy was then applied in A or B mode at doses of $12-20 \mathrm{j} / \mathrm{cm}^{2}$. Following combined treatment at 2-week intervals and 4 to 6 sessions, moderate improvement was observed in 3 patients, and excellent improvement in 2 . These patients were still receiving treatment at the end of the study period.

IPL was applied in 3 patients with melasma, in sun mode using the $B$ program at the doses of $16-20 \mathrm{j} / \mathrm{cm}^{2}$ at 4 -week intervals. Following 1 to 
3 sessions, mild improvement was observed in 1 patient and moderate improvement in 2, and it was decided not to continue the treatment. $\mathrm{Nd}$ :YAG was applied in genesis mode in 2 patients with keloid and 1 with atrophic scarring. Treatment was applied with 300-750 total pulses until the patient described severe burning. Only 1 session was performed, and no marked response was achieved. Treatment was discontinued at the patients' request.

$\mathrm{Nd}$ :YAG therapy was applied in genesis mode in 1 patient with onychomycosis in the fingernails in the form of at least 200 pulses per nail. No significant improvement was obtained after 2 sessions, and the treatment was discontinued at the patient's request because the procedure was very painful.

IPL was applied in B mode at $12-20 \mathrm{j} / \mathrm{cm}^{2}$ energy densities over 2 sessions in 1 patient with axillary pigmentation diagnosed with neurofibromatosis. A significant improvement was observed in the lesions from the first session, the patient did not continue treatment due to severe pain despite topical anesthesia.

$\mathrm{Nd}$ :YAG was applied in 1 patient with venous lake in the lip at a $5 \mathrm{~mm}$ spot diameter, $90 \mathrm{j} / \mathrm{cm}^{2}$ energy, and $10 \mathrm{~ms}$ pulse width. The lesion resolved entirely in a single session.

IPL in B mode with a $16-20 \mathrm{j} / \mathrm{cm}^{2}$ energy was applied in 3 sessions in 1 patient with poikiloderma of Civatte and another with diffuse scleroderma-related poikiloderma. Moderate improvement of poikiloderma was achieved with IPL.

\section{Discussion}

There are several studies in the literature concerning the use of $\mathrm{Nd}$ :YAG lasers and IPL systems for different indications in superficial cutaneous lesions ${ }^{1-36}$. These therapies have been used either alone or in combination with other medical treatments and laser systems in previous studies, and differing success rates have been reported. However, devices with different technologies also have different therapeutic parameters for each lesion and skin type. Direct comparisons between studies are therefore impossible.

The long-pulse 1064 nm Nd:YAG laser systems used in our study to treat superficial cutaneous lesions such as spider angioma, cherry angioma, and telangiectasia on the face and legs are reliable and effective. One of the largest-scale studies on this subject reported successful treatment of $100 \%$ of spider angiomas and $97 \%$ of facial telangiectasia ${ }^{2}$. Another study reported success rates of $63.2 \%$ in nevus flammeus, $80.0 \%$ in hemangiomas, $66.7 \%$ in telangiectasia, and $84.6 \%$ in other vascular lesions ${ }^{3}$. One study assessing the effectiveness of 532-nm potassiumtitanyl-phosphate (KTP) and Nd:YAG lasers in cherry angiomas reported that KTP lasers required significantly more sessions than Nd:YAG laser (1.35 and 1.11 sessions, respectively), but that more complications such as erythema, edema, pain, and scar formation occurred with $\mathrm{Nd}$ :YAG laser ${ }^{4}$. Nd:YAG laser is also quite effective in the treatment of venous lake in the lip ${ }^{5,6}$. John et al. ${ }^{5}$ reported that $\mathrm{Nd}$ :YAG laser therapy resulted in complete eradication of lesions in a single session in 20 out of 21 patients, with 95\% regression being observed in the remaining patient after 1 session and complete resolution after a second session. The efficacy of $\mathrm{Nd}$ :YAG laser in the treatment of superficial vascular lesions in our study was comparable with that reported in the previous literature.
Both IPL and Nd:YAG systems are regarded as effective in the treatment of rosacea ${ }^{1,7}$. Two studies comparing the effectiveness of IPL and pulsed dye laser (PDL), another commonly employed system, in the treatment of rosacea and facial erythema reported similar efficacy and safety for both ${ }^{8,9}$. While some studies have described Nd:YAG therapy as superior to PDL in the treatment of rosacea, others have reported similar efficacy but better tolerability in terms of pain ${ }^{10,11}$. Nd:YAG laser has been reported to be effective in both ETR and PPR, but to be more successful in the treatment of ETR ${ }^{1}$. In our study, ETR represents $94.11 \%$ of all rosacea patients. We used Nd:YAG and IPL in combination at twoweek intervals in our study and achieved very good improvement at a level of $88 \%$ and moderate improvement in the remaining cases. Since PPR patients in our clinic are generally under systemic treatment that can result in photosensitivity, laser therapy is planned after the regression of the existing inflammatory lesions. There were only 2 PPR patients in our study, and moderate improvement was achieved in both using combined treatment with topical azelaic acid therapy.

We encountered no previous studies assessing the effectiveness of $\mathrm{Nd}$ :YAG laser and IPL in combination in the treatment of rosacea in the available literature. In their study published in 2017, Liu et al. ${ }^{12}$ applied Nd:YAG and IPL in combination in the same session and also consecutively, Nd:YAG 3 days after IPL, in the treatment of facial telangiectasia independently of diagnosis of rosacea. Both methods were determined to be effective, although combined application was more effective than consecutive application, but was also more painful. Erythema, purpura, and development of edema are more common $48 \mathrm{~h}$ after treatment in areas receiving combined therapy, but no scar formation has been reported. In our study, the two laser options were used consecutively at intervals of at least 2 weeks in rosacea patients, and no complications were observed. Ours is the first study to demonstrate the effectiveness of combined therapy in rosacea. Our patients reported an intense burning sensation and pain during IPL application, while Nd:YAG therapy was better tolerated. We think that the combined use of Nd:YAG and IPL, albeit at intervals, can increase therapeutic success in rosacea without involving additional risks since different targets will be treated at different wavelengths.

$\mathrm{Nd}$ :YAG and IPL systems have been reported to be individually effective in the treatment of nevus flammeus ${ }^{13-20}$. However, there have been no previous studies of their combined use. Treatment has been found to be more effective in patients who developed bullae and dark and light gray colorings after laser treatment ${ }^{13}$. In our study, too, the target dose was determined as that in which mild, light gray coloring was observed. Treatments are more successful in purple lesions compared to pink lesions, and when located in the neck rather than in the face ${ }^{13,14}$. Treatment in our study was also more effective when the lesions were in the neck, and almost complete elimination of lesions was achieved with IPL alone. IPL therapy in nevus flammeus in previous studies has generally been applied over 3 to 6 sessions at 4- to 6-week intervals, and at least moderate success has been reported in more than half of patients ${ }^{15-18}$. IPL therapy is also thought to be capable of bestowing additional benefit in nevus flammeus resistant to $\mathrm{PDL}^{19,20}$.

Studies evaluating the efficacy of combined PDL and Nd:YAG in nevus flammeus have generally reported successful outcomes ${ }^{21,22}$, although one study comparing the effectiveness of combined therapy with PDL alone reported no additional benefit of combination therapy over PDL 
alone, and that it also involved disadvantages such as scar formation ${ }^{23}$ A combination of different wavelengths in the same session is thought to bestow additional benefit, particularly in the case of treatmentresistant lesions. In our study, Nd:YAG and IPL therapies were applied in combination at 2-week intervals. This resulted in excellent improvement in $37.5 \%$ of cases of nevus flammeus and moderate improvement in the remainder. No complications were observed at controls during sessions performed at 2-week intervals. Ours is the first study to assess the effectiveness of combined Nd:YAG and IPL in the treatment of nevus flammeus. We think that combination therapy at 2-week intervals can extend the treatment period while bestowing additional benefit with no additional risk.

The laser system the efficacy of which has been most studied in infantile hemangioma is PDL. However, Nd:YAG lasers have also been shown to be $87.57 \%$ effective, and to be more successful in the treatment of superficial lesions in particular ${ }^{24,25}$. The efficacy of a combination of $\mathrm{Nd}: Y A G$ and PDL in the same session has been shown to be $92.6 \%$ in infantile hemangiomas ${ }^{26}$. To the best of our knowledge, the effectiveness of a combination of IPL and Nd:YAG in infantile hemangioma has not been evaluated previously. In our study, we combined IPL and Nd:YAG therapies at 2-week intervals and achieved moderate improvement in 3 out of 5 patients with infantile hemangiomas and excellent improvement in 2.

IPL therapy has been reported to be quite successful in the treatment of solar lentigines ${ }^{27-29}$. One study of 31 women with solar lentigines on the hands reported more than $50 \%$ improvement in $62 \%$ of patients following treatment over 3 to 5 sessions at 1-month intervals, with improvement exceeding $75 \%$ in $23 \%$ of these ${ }^{28}$. Another study reported marked improvement with a single session of IPL in all solar lentigines on the hands and face ${ }^{27}$. Very good improvement was achieved in our study with IPL in all lesions on the back of the hand, while excellent improvement was determined in $43 \%$ of facial lesions and moderate improvement in the remaining cases. We attributed the lower success rate in the face to the selection of relatively lower doses than those used on the hands in order to avoid complications.

One study from Turkey described a combination of IPL and Nd:YAG applied at 2-week intervals as more successful in hand rejuvenation than $\mathrm{Nd}$ :YAG therapy alone ${ }^{30}$. In our study, in addition to the improvement of lesions in all the patients in whom we applied IPL alone for solar lentigines and scanned the entire back of the hand, we also observed a decrease in signs of photoaging and fine wrinkles in the skin of the hand.

IPL is known to be an effective technique for treating melasma due to its ability to target epidermal and dermal lesions. Moderate-good improvement has been reported in more than half of patients with three to four sessions of IPL administered at intervals of three to five weeks. Treatment is more effective in epidermal-type melasma $29,31,32$. In our study, moderate improvement was achieved in 2 and mild improvement in 1 of 3 patients with both epidermal and dermal component melasma after IPL therapy. IPL was also applied for axillary pigmentation associated with neurofibromatosis, and excellent improvement was achieved in the areas of application, but treatment was discontinued of the patient's own volition.

IPL systems are also generally effective in the treatment of poikiloderma ${ }^{33-36}$. We achieved moderate improvement, compatible with the previous literature, in a patient diagnosed with poikiloderma of Civatte and scleroderma.

All studies comparing IPL and Nd:YAG systems in terms of pain have used therapies for purposes of epilation. However, since the systems used differ, it is not possible to perform any direct comparison between them, although, in contrast to our findings, studies have generally reported that IPL systems caused less pain than Nd:YAG procedures ${ }^{37-41}$. Goh $\mathrm{CL}$ reported that patients described a prolonged burning sensation with the IPL system, but a transient stinging sensation with $\mathrm{Nd}$ :YAG ${ }^{41}$. We thing that with its own cooling headpiece, the $\mathrm{Nd}$ :YAG system used in our study was effective in overcoming pain by cooling the area before treatment.

Complications develop with varying frequencies with both IPL and $\mathrm{Nd}$ :YAG laser procedures, depending on the indication, the device used, the procedure parameters selected, and the patient's skin type. The most common complications are erythema, purpura, bullae, crust, hypo/hyperpigmentation, infection, and scar formation ${ }^{42}$. The risk of post-inflammatory hyperpigmentation and atrophic scar formation is higher in patients with skin types 4 and 5. Studies comparing IPL and $\mathrm{Nd}$ :YAG in terms of complications have reported a higher incidence of hyperpigmentation development in vascular lesions with $\mathrm{Nd}: \mathrm{YAG}^{43}$. In contrast, a greater incidence of bullae and post-inflammatory hyperpigmentation has been reported with IPL used for epilation purposes than with Nd:YAG laser ${ }^{41}$. Complications developed in only 3 patients in our study (vesicles in 2, and atrophic scar in 1), all of which occurred after Nd:YAG laser application. Although it is not possible to perform a direct comparison between studies due to differences in the devices used, application parameters, and patient skin types, we attribute the low complication rate in our study to a lighter skin type of our patients, to our taking greater care in the selection of application parameters and informing patients about sun protection, to routine post-procedural cold application, and to the use of topical corticosteroids.

\section{Study Limitations}

The principal limitation of our study is that the number of patients was not sufficient to permit evaluation of effectiveness for every indication. Our retrospective review of applications performed in only the first year restricted the number of cases enrolled. This problem can be overcome with future larger-scale prospective studies. Our study may contribute to such studies.

\section{Conclusion}

In our one-year study period, Nd:YAG and IPL therapies both achieved successful outcomes in a wide area of indications, with relatively low complication rates. The risk of complications may be worrying for physicians newly embarking on laser therapy, and may lead to the selection of more traditional therapeutic methods in which experience is greater in appropriate indications. However, it is very probable that as experience with laser therapy increases and when appropriate parameters are used, cosmetically more acceptable, successful cosmetic results will be achieved compared to electrocauterization, cryotherapy, or other invasive surgical procedures. We therefore think that broadening the use of laser devices in training and research hospitals right from the intern period will increase their therapeutic effectiveness 
and enable the correct parameters and the variety of indications in treatment to be determined.

Our study represents the first analysis in the literature of the effectiveness of Nd:YAG and IPL therapies in combination applied at 2-week intervals in rosacea, nevus flammeus and hemangioma. We think that combinations applied at different sessions can prolong the duration of treatment and bestow additional benefits with no additional risk compared to combinations applied in the same session, since each wave length will have a separate target. Further comparative and larger-scale studies for each indication are now needed to prove this hypothesis.

We think that our study results can serve as a guide for newly established units, encourage new applications, and shed light on future studies by revealing the first-year experience of a newly opened laser unit in a university hospital dermatological and venereal diseases department.

\section{Ethics}

Ethics Committee Approval: The study was approved by the Karadeniz Technical University Faculty of Medicine Clinical Research Ethics Committee (approval number: 43, date: 2017).

Informed Consent: Written informed consent have been obtained from the patients.

Peer-review: External and internal peer-reviewed.

\section{Authorship Contributions}

Surgical and Medical Practices: D.A.A., L.B.S., Concept: D.A.A., Design: D.A.A., Data Collection or Processing: D.A.A., L.B.S., S.B., Analysis or Interpretation: D.A.A., L.B.S., Literature Search: D.A.A. Writing: D.A.A., L.B.S., S.Y., S.BA.

Conflict of Interest: No conflict of interest was declared by the authors. Financial

\section{References}

1. Say EM, Okan G, Gökdemir G. Treatment Outcomes of Long-Pulsed Nd: YAG laser for Two Different Subtypes of Rosacea. J Clin Aesthet Dermatol 2015;8:16-20

2. Ozyurt K, Colgecen E, Baykan H, et al. Treatment of superficial cutaneous vascular lesions: experience with the long-pulsed 1064 nm Nd: YAG laser. Scientific World Journal 2012;2012:197139.

3. Civas $E, \operatorname{Koc} E, A k s o y B$, et al. Clinical experience in the treatment of different vascular lesions using a neodymium-doped yttrium aluminum garnet laser. Dermatol Surg 2009;35:1933-41.

4. Pancar GS, Aydin F, Senturk N, et al. Comparison of the 532-nm KTP and 1064-nm Nd: YAG lasers for the treatment of cherry angiomas. J Cosmet Laser Ther 2011;13:138-41.

5. John HE, Phen HS, Mahaffey PJ. Treatment of venous lesions of the lips and perioral area with a long-pulsed Nd: YAG laser. Br J Oral Maxillofac Surg 2016:54:376-8

6. Mlacker $\mathrm{S}$, Shah VV, Aldahan AS, et al. Laser and light-based treatments of venous lakes: a literature review. Lasers Med Sci 2016;31:1511-9.

7. Liu J, Liu J, Ren Y, et al. Comparative efficacy of intense pulsed light for different erythema associated with rosacea. J Cosmet Laser Ther 2014;16:324-7.

8. Neuhaus IM, Zane LT, Tope WD. Comparative efficacy of non-purpuragenic pulsed dye laser and intense pulsed light for erythematotelangiectatic rosacea. Dermatol Surg 2009;35:920-8

9. Handler MZ, Bloom BS, Goldberg DJ. IPL vs PDL in treatment of facial erythema: a split-face study. J Cosmet Dermatol 2017;16:450-3.

10. Salem SA, Abdel Fattah NS, Tantawy SM, et al. Neodymium-yttrium aluminum garnet laser versus pulsed dye laser in erythemato-telangiectatic rosacea: comparison of clinical efficacy and effect on cutaneous substance (P) expression. J Cosmet Dermatol 2013;12:187-94

11. Alam M, Voravutinon $N$, Warycha $M$, et al. Comparative effectiveness of non-purpuragenic 595-nm pulsed dye laser and microsecond 1064-nm neodymium-yttrium-aluminum-garnet laser for treatment of diffuse facial erythema: A double-blind randomized controlled trial. J Am Acad Dermatol 2013:69:438-43

12. Liu J, Zhou BR, Wu D, et al. Sequential delivery of intense pulsed light and long-pulse 1.064-nm neodymium-doped yttrium aluminum garnet laser shows better effect in the treatment of facial telangiectasias than using them separately. G Ital Dermatol Venereol 2017;152:1-7.

13. Zhong SX, Liu YY, Yao L, et al. Clinical analysis of port-wine stain in 130 Chinese patients treated by long-pulsed 1064-nm Nd: YAG laser. J Cosmet Laser Ther 2014;16:279-83.

14. Wang $B$, Wu Y, Zhu $X$, et al. Treatment of neck port-wine stain with intense pulsed light in Chinese population. J Cosmet Laser Ther 2013;15:85-90.

15. Dong $X, Y u Q$, Ding J, et al. Treatment of facial port-wine stains with a new intense pulsed light source in Chinese patients. J Cosmet Laser Ther 2010;12:183-7.

16. Adatto MA, Luc-Levy J, Mordon S. Efficacy of a novel intense pulsed light system for the treatment of port wine stains. J Cosmet Laser Ther 2010;12:54-60.

17. Li G, Lin T, Wu Q, et al: Clinical analysis of port wine stains treated by intense pulsed light. J Cosmet Laser Ther 2010;12:2-6.

18. Ozdemir M, Engin B, Mevlitoğlu I. Treatment of facial port-wine stains with intense pulsed light: a prospective study. J Cosmet Dermatol 2008;7:127-31.

19. Babilas P, Schreml S, Eames T, et al. Split-face comparison of intense pulsed light with short- and long-pulsed dye lasers for the treatment of port-wine stains. Lasers Surg Med 2010;42:720-7.

20. Bjerring P, Christiansen K, Troilius A. Intense pulsed light source for the treatment of dye laser resistant port-wine stains. J Cosmet Laser Ther 2003:5:7-13

21. Bencini PL, Tourlaki A, Tretti Clementoni M, et al. Double phase treatment with flashlamp-pumped pulsed-dye laser and long pulsed Nd: YAG laser for resistant port wine stains in adults. Preliminary reports. G Ital Dermatol Venereol 2016;151:281-6.

22. Tu HD, Li YH, Xie HF, et al. A split-face study of dual-wavelength laser on neck and facial port-wine stains in Chinese Patients. J Drugs Dermatol 2015;14:1336-40

23. Wang T, Chen D, Yang J, et al. Safety and efficacy of dual-wavelength laser $(1064+595 \mathrm{~nm})$ for treatment of non-treated port-wine stains. J Eur Acad Dermatol Venereol 2017.

24. Chinnadurai S, Sathe NA, Surawicz T. Laser treatment of infantile hemangioma: a systematic review. Lasers Surg Med 2016;48:221-33.

25. Zhong SX, Tao YC, Zhou JF, et al. Infantile hemangioma: clinical characteristics and efficacy of treatment with the long-pulsed 1,064-nm neodymium-doped yttrium aluminum garnet laser in 794 Chinese Patients. Pediatr Dermatol 2015;32:495-500

26. Kaune KM, Lauerer $P$, Kietz $S$, et al. Combination therapy of infantile hemangiomas with pulsed dye laser and Nd: YAG laser is effective and safe. J Dtsch Dermatol Ges 2014;12:473-8.

27. Tanaka $Y$, Tsunemi $Y$, Kawashima M. Objective assessment of intensive targeted treatment for solar lentigines using intense pulsed light with wavelengths between 500 and $635 \mathrm{~nm}$. Lasers Surg Med 2016;48:30-5.

28. Sasaya $H$, Kawada A, Wada T, et al. Clinical effectiveness of intense pulsed light therapy for solar lentigines of the hands. Dermatol Ther 2011;24:584-6.

29. Konishi N, Kawada A, Kawara S, et al. Clinical effectiveness of a novel intense pulsed light source on facial pigmentary lesions. Arch Dermatol Res 2008;300 Suppl 1:S65-7.

30. Oktem A, Kocyigit P. Comparison of effectiveness of 1,064-nm Nd: YAG laser and Nd: YAG laser-IPL combination treatments in hand skin rejuvenation. J Cosmet Laser Ther 2016;18:270-4

31. Zoccali G, Piccolo $D$, Allegra $P$, et al. Melasma treated with intense pulsed light. Aesthetic Plast Surg 2010;34:486-93. 
32. Li YH, Chen JZ, Wei HC, et al. Efficacy and safety of intense pulsed light in treatment of melasma in Chinese patients. Dermatol Surg 2008;34:693 700; discussion 700-1.

33. Scattone L, de Avelar Alchorne MM, Michalany N, et al. Histopathologic changes induced by intense pulsed light in the treatment of poikiloderma of Civatte. Dermatol Surg 2012;38:1010-6.

34. Campolmi P, Bonan P, Cannarozzo G, et al. Intense pulsed light in the treatment of non-aesthetic facial and neck vascular lesions: report of 85 cases. J Eur Acad Dermatol Venereol 2011;25:68-73.

35. Dinsdale G, Murray A, Moore T, et al. A comparison of intense pulsed light and laser treatment of telangiectases in patients with systemic sclerosis: a within-subject randomized trial. Rheumatology (Oxford) 2014;53:1422-30.

36. Murray AK, Moore TL, Richards $\mathrm{H}$, et al. Pilot study of intense pulsed light for the treatment of systemic sclerosis-related telangiectases. $\mathrm{Br} J$ Dermatol 2012;167:563-9.

37. Szima GZ, Janka EA, Kovács A, et al. Comparison of hair removal efficacy and side effect of neodymium:yttrium-aluminum-garnet laser and intense pulsed light systems (18-month follow-up). J Cosmet Dermatol 2017;16:193-8.
38. Bs B, Chittoria RK, Thappa DM, et al. Are lasers superior to lights in the photoepilation of Fitzpatrick $\mathrm{V}$ and $\mathrm{VI}$ skin types?-A comparison between Nd: YAG laser and intense pulsed light. J Cosmet Laser Ther 2017;19:252 255.

39. Karaca Ş, Kaçar SD, Ozuğuz P. Comparison of SHR Mode IPL system with Alexandrite and Nd: YAG lasers for leg hair reduction. Balkan Med J 2012;29:401-5.

40. Ismail SA. Long-pulsed Nd: YAG laser vs. intense pulsed light for hair removal in dark skin: a randomized controlled trial. Br J Dermatol 2012;166:317-21.

41. Goh CL. Comparative study on a single treatment response to long pulse $\mathrm{Nd}$ : YAG lasers and intense pulse light therapy for hair removal on skin type IV to VI-is longer wavelengths lasers preferred over shorter wavelengths lights for assisted hair removal. J Dermatolog Treat 2003;14:243-7.

42. Gunaydın A, Dereli T. Complications of laser. Turkderm 2012;46:48-51.

43. Fodor $L$, Ramon $Y$, Fodor $A$, et al. A side-by-side prospective study of intense pulsed light and Nd:YAG laser treatment for vascular lesions. Ann Plast Surg 2006;56:164-70. 